\title{
ALTERNATIVNE ŽITARICE U SRBIJI U SISTEMU ODRŽIVE POLJOPRIVREDNE PROIZVODNJE
}

\author{
ALTERNATIVE CEREALS IN SERBIA IN THE SYSTEM OF \\ SUSTAINABLE AGRICULTURAL PRODUCTION
N. Đurić, Đ. Glamočlija, Snežana Janković, Gordana Dozet, Vera Popović, Milena Glamočlija, V. Cvijanović

\section{SAŽETAK}

Suvremena ratarska proizvodnja ima izraženo geografsko, ekološko, ekonomsko i društveno obilježje. Prema navedenim osobinama može se podijeliti na tradicionalnu, konvencionalnu i održivu poljoprivredu. Tradicionalna ratarska proizvodnja u nas prevladava na malim obiteljskim imanjima. Poljoprivredni proizvodi koriste se za potrebe članova domaćinstva i ostaje malo tržišnih viškova. Unapređenje ovog sistema proizvodnje je u izmjeni strukture sjetve, odnosno uvođenju alternativnih ratarskih vrsta čiji proizvodi imaju veću tržišnu vrijednost. Za male farmere interesantan je i sistem održive poljoprivredne proizvodnje u okviru čega se izdvajaju tri sistema uzgajanja ratarskih biljaka. To su dobra poljoprivredna praksa, integralna i organska (ekološka ili biološka) poljoprivredna proizvodnja. Ukoliko se proizvođači odluče za neki od ova tri sistema uzgajanja, biljne vrste iz grupe alternativnih žita mogu biti pravi izbor, jer osiguravaju tržište kvalitetnim i zdravstveno sigurnim prehrambenim proizvodima. Prije nego što se odluče za ove sisteme proizvodnje farmeri treba da steknu neophodna predznanja.

Ključne riječi: alternativna žita, privredna važnost, vrste, sistemi uzgajanja, prinosi, upotreba

\begin{abstract}
Contemporary crop production has a pronounced geographical, ecological, economic and social significance. By these characteristics it can be divided into traditional, conventional and sustainable agriculture. In our country, traditional crop production exists predominantly on small family farms. Agricultural products are used for the needs of house hold members, leaving few market surpluses. The improvement of this production system is in changing the
\end{abstract}


sowing structure, i.e. introduction of alternative crop species with higher market value products. For small farmers, a system of sustainable agricultural production is also interesting, where three systems of crop cultivation can be distinguished: good agricultural practices, integral and organic (ecological or biological) agricultural production. If producers choose one of these three cultivation systems, species from the alternative cereals group can be the right choice as they provide the market with quality and sanitarily safe food products. Before opting for these production systems, farmers need to asquire the necessary background knowledge.

Key words: alternative cereals, economic importance, species, systems of cultivation, yield, utilization

\section{UVOD}

Najvažnijoj grupi ratarskih biljaka koje se nazivaju žita pripadaju jednogodišnje vrste iz porodice trava (fam. Poaceae) koje se uzgajaju radi jednosjemenskih plodova zrna. U ishrani ljudi, domaćih i uzgajanih životinja zrna imaju značajnu ulogu, jer su bogata lako probaavljivim ugljkohidratima i bjelančevinama. Na samim počecima bavljenja ratarskom proizvodnjom, prije oko 10.000 godina, čovjek je kultivirao prve samonikle vrste koje su pripadale porodici trava. Na području istočnog Mediterana uvedeno je u proizvodnju nekoliko vrsta pšenice, zatim ječam, raž i zob; u istočnoj Aziji počeli su uzgajati rižu i proso; u Africi sirak i nekoliko prosolikih vrsta; u srednjoj Americi kukuruz. Ove vrste su pripadale porodici trava, imale su srodne biološke osobine i na približno isti način su uzgajane i korištene. Tijekom duge povijesti civilizacije, ratarska proizvodnja se usavršavala, između ostalog i uvođenjem novih vrsta u sustav uzgajanja. Po suvremenoj klasifikaciji ova grupa naziva se zrnate škrobne biljke ili žita, a obuhvaća preko 20 vrsta. Prema botaničkoj pripadnosti, biološkim osobinama i uvjetima uspijevanja žitarice su podjeljene na prava (krušna), prosolika i alternativna (Đurić i sur., 2015.). Prvoj podgrupi pripadaju ozime i proljetne vrste guste sjetve čije zrno služi za izradu krušnopekarskih proizvoda. To su sve uzgajane pšenice, ječam, zob, raž i tritikale. Prosolika žita su kukuruz, sirak, sve vrste prosa i kanarska trava.

Vrste, koje se danas uzgajaju radi zrna sličnog su kemijskog sastava, i uz primjenu agrotehnike kao za žita, također pripadaju ovoj velikoj porodici ratarskih biljaka i nazivaju se alternativna žita. Ovoj grupi pripadaju vrste iz drugih botaničkih porodica koje se uzgajaju radi zrna koje se koristi kao i zrno žita. Najvažnije vrste ove podgrupe su heljda, kvinoja i štir. 
Danas u ratarskoj praksi termin „alternativna“ ima šire značenje i često se odnosi na one vrste žita koje se uzgajaju u specifičnim agroekološkim uvjetima i na manjim površinama. Prema ovom principu podjele, uz nabrojane, grupi alternativnih žita pripadaju rijetko uzgajane pšenice krupnik, jednozrnac, dvozrnac, tvrda, patuljasta i korasan pšenica. Golozrne forme ječma i zobi, također se mogu nazvati alternativna žita, zatim kukuruz šećerac, kokičar i tvrdunac, kanarska trava, brojne vrste prosa, kao i miskantus (Glamočlija i sur., 2012.).

\section{AGROEKOLOŠKI UVJETI POLJOPRIVREDNIH PODRUČJA SRBIJE}

Republika Srbija je u umjerenom klimatskom pojasu između $44^{\circ} 47^{\prime}$ i $46^{\circ} 12^{\prime}$ sjeverne geografske širine. Ukupne poljoprivredne površine zauzimaju preko $65 \%$ teritorija RSrbije. Poljoprivredna područja, najprikladnija za ratarsku proizvodnju, prema zemljišnim i klimatskim uvjetima, mogu se podijeiti u dvije osnovne cjeline. To su ravničarsko područje, do $200 \mathrm{~m}$ nadmorske visine i brdsko-planinsko ili prelazno do $500 \mathrm{~m}$ nadmorske visine. Osim razlike u nadmorskoj visini ova područja se razlikuju i po zemljišnim i klimatskim uvjetima (tablice 1 i 2 ).

Tablica 1. Prevladavajući tipovi zemljišta, hektara

Table 1 Prevalent soil types, hectares

\begin{tabular}{|l|c|c|}
\hline \multicolumn{1}{|c|}{$\begin{array}{c}\text { Tip zemljišta } \\
\text { Soil type }\end{array}$} & $\begin{array}{c}\text { Ravničarska područja } \\
\text { Lowland areas }\end{array}$ & $\begin{array}{c}\text { Brdsko-planinskea područja } \\
\text { Hilly-mountainous areas }\end{array}$ \\
\hline $\begin{array}{l}\text { Černozem } \\
\text { Chernozem }\end{array}$ & 1.212 .700 & - \\
\hline $\begin{array}{l}\text { Gajnjača } \\
\text { Cambisol }\end{array}$ & 77.000 & 650.500 \\
\hline $\begin{array}{l}\text { Smonica } \\
\text { Vertisol }\end{array}$ & 35.300 & 341.800 \\
\hline $\begin{array}{l}\text { Pseudoglej } \\
\text { Pseudogley }\end{array}$ & 17.000 & 100.900 \\
\hline $\begin{array}{l}\text { Ritska crnica } \\
\text { Humogley }\end{array}$ & 336.700 & 325.000 \\
\hline $\begin{array}{l}\text { Alivijumska zemljišta } \\
\text { Alluvium soils }\end{array}$ & 250.500 & - \\
\hline $\begin{array}{l}\text { Slatinasta zemljišta } \\
\text { Saline soils }\end{array}$ & 242.200 & 138.900 \\
\hline $\begin{array}{l}\text { Ostali tipovi zemljišta } \\
\text { Other soil types }\end{array}$ & 23.000 & - \\
\hline
\end{tabular}


N. Đurić i sur.: Alternativne žitarice u Srbiji

u sistemu održive poljoprivredne proizvodnje

Tablica 2. Prosječni klimatski uvjeti, mjesečni raspored padalina i topline ( $\left.\mathrm{mm} \operatorname{and}^{0} \mathrm{C}\right)$

Table 2 Average climatic conditions, monthly precipitation and heat distribution ( $\mathrm{mm}$ and ${ }^{\circ} \mathrm{C}$ )

\begin{tabular}{|l|c|c|c|c|}
\hline \multirow{2}{*}{ Mjesec } & \multicolumn{2}{|c|}{ Ravničarska područja } & \multicolumn{2}{c|}{ Brdsko-planinska područja } \\
\cline { 2 - 5 } \multirow{2}{*}{ Month } & Padaline & \multicolumn{2}{c|}{ Temperature } & \multicolumn{2}{c|}{ Padaline } & Temperature \\
\cline { 2 - 5 } & \multicolumn{2}{|c|}{ Lowland areas } & \multicolumn{2}{c|}{ Hilly-mountainous areas } \\
\hline 1. & Precipitation & Temperature & Precipitation & Temperature \\
\hline 2. & 42 & 0,7 & 48 & 0,5 \\
\hline 3. & 37 & 2,4 & 39 & 2,2 \\
\hline 4. & 48 & 7,7 & 46 & 7,5 \\
\hline 5. & 49 & 13,6 & 52 & 12,1 \\
\hline 6. & 66 & 18,5 & 59 & 17,2 \\
\hline 7. & 88 & 21,1 & 85 & 20,1 \\
\hline 8. & 66 & 22,8 & 65 & 22,4 \\
\hline 9. & 52 & 22,7 & 57 & 21,2 \\
\hline 10. & 45 & 18,2 & 55 & 17,0 \\
\hline 11. & 55 & 12,0 & 55 & 12,2 \\
\hline 12. & 51 & 7,3 & 50 & 7,5 \\
\hline $\begin{array}{l}\text { Suma, prosjek } \\
\text { Sum, average }\end{array}$ & 650 & 2,8 & 53 & 2,7 \\
\hline
\end{tabular}

Prvoj cjelini pripadaju ravničarske oblasti Vojvodine i centralne Srbije. To su predjeli koji se nalaze u Panonskoj nizini. Odlikuju se povoljnim klimatskim i zemljišnim uvjetima za intenzivnu ratarsku proizvodnju (Glamočlija i sur. 2015.), iako je mjesečni raspored padalina promjenljiv i često izložen utjecajima različitih zračnih strujanja. Količine padalina u pojedinim godinama su značajno manje od optimalnih potreba biljaka. Sušni period se dijelom ublažava dobrim fizičkim osobinama zemljišta, kao i primjenom adekvatnih agrotehničkih mjera. U cjelini, povoljniji vodni režim je u zapadnim i južnim predjelima dok se količine i raspored padalina postepeno smanjuju idući ka istočnim i sjeveroistočnim. U ravničarskim područjima prevladavaju ratarske vrste kukuruza zubana, obična pšenica, ječam, suncokret, soja, šećerna repa i lucerna, dok su ostale vrste manje zastupljene, pa i alternativna žita.

Druga ratarska područja su na većim nadmorskim visinama (do $500 \mathrm{~m}$ ) i ona obuhvaćaju brdsko-planinaska (prijelazna) područja centralne Srbije. Brdsko-planinski predjeli zauzimaju veći teritorij tako da zemljišni i klimatski uvjeti ovise o geografskom položaju i nadmorskoj visini (Maksimović et al., 2016.). Na nižim brdskim predjelima zapadne Srbije klimatski uvjeti su 
povoljniji, s većom količinom padalina, zemljišta su boljih kemijskih i fizičkih osobina. U istočnim predjelima manje su količine padalina i nepovoljniji raspored tijekom vegetacijske sezone, dok su zemljišta sličnih osobina. S povećanjem nadmorske visine poljoprivredne površine se nalaze na plićim i manje plodnim zemljištima. Klimatski uvjeti, kako raspored topline, tako i vodni režim, manje su povoljni i ograničavaju dužinu vegetacijske sezone. U takvim toplinskim uvjetima mogu se uzgajati ratarske vrste kraćeg vegetacijskog razdoblja, koje uspjevaju na nižim temperaturama i bolje podnose zimske mrazeve s visokim snježnim pokrivačem (Glamočlija et al., 2010.). Najzastupljenija su prava žita zob, raž, kao i proljetne sorte pšenice i ječma. Ovo područje je povoljno za uzgajanje alternativnih žita heljde, prosa, kvinoje, krupnika, korasan pšenice, kanarske trave, golozrnog ječma i zobi u sistemu održive poljoprivredne proizvodnje (Stallknecht et al., 1995.; Kajgana i sur. 2004.; Jankovic et al., 2011.; Ikanovićet et al., 2014.; Jevđović i sur. 2015.).

\section{REZULTATI ISTRAŽIVANJA I DISKUSIJA}

Alternativna žita su biljke koje se u svijetu uzgajaju na manjim poljoprivrednim površinama, najčešće u sistemima održive $i$ ekološke poljoprivredne proizvodnje. U R Srbiji površine pod alternativnim žitima su još uvijek nedovoljne da podmire sve veće potrebe za njihovim proizvodima, pa smo prinuđeni da ih uvozimo (Glamočlija, 2012.; Đurić i sur. 2015.).

Potrebe ovih biljaka prema agroekološkim uvjetima slične su kao i za žita velikih površina. Alternativne biljke, botanički srodne pravim žitima, u navedenim predjelima, mogu se uzgajati primjenom tehnologije proizvodnje za ozime i proljetne sorte pšenice. Različite forme kukuruza, zatim kanarska trava, sirkovi, prosa i miskantus usjevi su proljetne sjetve i uzgajaju se slično kao i kukuruz. Heljda, kvinoja, štir i još neke, za nas nove vrste, biljke su porijeklom iz predjela $\mathrm{s}$ manje povoljnim klimatskim i zemljišnim uvjetima. Na našim poljoprivrednim površinama daju veće prinose i hranjivu vrijednost zrna nego u zemljama porijekla tako da se sve više koriste u pripremi funkcionalne hrane i različitih bio-proizvoda (Žeželj i sur. 1995.; Stikic et al., 2012.; Sikora i sur. 2013.; Glamočlija i sur. 2017.). Tehnologija proizvodnje ovih biljaka predstavlja kombinaciju uzgoja uskorednih i širokorednih žita, a izvodi se standardnom poljoprivrednom mehanizacijom.

Heljda je biljka višestruke upotrebe. Glavni proizvod oljušteno zrno (plod orašica) koristi se za spremanje različitih prehrambenih proizvoda. Nutricionisti 
je svrstavaju u grupu biljaka prikladnih za spremanje funkcionalne hrane. Ljuske služe za punjenje jastuka i posteljine, a stabljike u farmaceutskoj industriji (Đurić i sur. 2015.). Heljda je medonosna biljka. U našim poljoprivrednim područjima bila je zastupljena u strukturi sjetve, posebno na većim nadmorskim visinama, ali je proizvodnja skoro ugašena tijekom XX stoljeća. U proteklim desetljećima heljda se sve više uzgaja i koristi u ishrani zbog svoje visoke nutritivne i zdravstvene vrijednosti (Popović et al., 2013.). Prema ostvarenim prinosima u redovnoj proizvodnji i brojnim rezultatima naučnih istraživanja odlično uspijeva u agroekološkim uvjetima Srbije, posebno u brdsko-planinskim predjelima gdje, uz visoke prinose daje i odličnu kvalitetu zrna. Ovo potvrđuju i naša prethodna istraživanja (tablica 3 ).

Tablica 3. Uticaj agroekoloških uvjeta na visinu stabljike (cm) i prinos zrna heljde (t ha $\left.{ }^{-1}\right)$

Table 3 Effect of agroecological conditions on stalk height (cm) and grain yield of buckwheat $\left(\mathrm{t} \mathrm{ha}^{-1}\right)$

\begin{tabular}{|c|c|c|c|c|c|c|}
\hline $\begin{array}{l}\text { Parametar } \\
\text { Parameter }\end{array}$ & $\begin{array}{l}\text { Lokalitet } \\
\text { Site }\end{array}$ & $\begin{array}{l}\text { Godina } \\
\text { Year }\end{array}$ & $\begin{array}{c}\text { Visina stabljike } \\
\text { Stalk height }\end{array}$ & $\begin{array}{c}\text { Prosjek } \\
\text { Average }\end{array}$ & \multicolumn{2}{|c|}{$\mathrm{LSD}_{\mathrm{ABC}}$} \\
\hline \multirow{6}{*}{$\begin{array}{l}\text { Visina stabljike } \\
\text { Stalk height }\end{array}$} & \multirow{2}{*}{ Nova Pazova } & 2011. & 114,40 & \multirow{2}{*}{116.20} & \multirow{6}{*}{2,66} & \multirow{6}{*}{3,63} \\
\hline & & 2012. & 118,00 & & & \\
\hline & \multirow{2}{*}{ Valjevo } & 2011. & 103,60 & \multirow{2}{*}{102.70} & & \\
\hline & & 2012. & 101,80 & & & \\
\hline & \multirow{2}{*}{ Nova Varoš } & 2011. & 90,40 & \multirow{2}{*}{91.30} & & \\
\hline & & 2012. & 92,20 & & & \\
\hline \multirow{2}{*}{$\begin{array}{l}\text { Prosjek } \\
\text { Average }\end{array}$} & & 2011. & 102,80 & \multirow{2}{*}{103,4} & \multirow{2}{*}{3,77} & \multirow{2}{*}{5,14} \\
\hline & & 2012. & 104,00 & & & \\
\hline $\begin{array}{l}\text { Parametar } \\
\text { Parameter }\end{array}$ & $\begin{array}{l}\text { Lokalitet } \\
\text { Site }\end{array}$ & $\begin{array}{c}\text { Godina } \\
\text { Year }\end{array}$ & $\begin{array}{l}\text { Prinos zrna } \\
\text { Grain yield }\end{array}$ & $\begin{array}{l}\text { Prosjek } \\
\text { Average }\end{array}$ & \multicolumn{2}{|c|}{$\mathrm{LSD}_{\mathrm{ABC}}$} \\
\hline \multirow{6}{*}{$\begin{array}{l}\text { Prinos zrna } \\
\text { Grain yield }\end{array}$} & \multirow{2}{*}{ Nova Pazova } & 2011. & 1,57 & \multirow{2}{*}{1,65} & \multirow{6}{*}{0,04} & \multirow{6}{*}{0,05} \\
\hline & & 2012. & 1,73 & & & \\
\hline & \multirow{2}{*}{ Valjevo } & 2011. & 0,89 & \multirow{2}{*}{0,80} & & \\
\hline & & 2012. & 0,71 & & & \\
\hline & \multirow{2}{*}{ Nova Varoš } & 2011. & 1,31 & \multirow{2}{*}{1,31} & & \\
\hline & & 2012. & 1,30 & & & \\
\hline \multirow{2}{*}{$\begin{array}{l}\text { Prosjek } \\
\text { Average }\end{array}$} & & 2011. & 1,24 & \multirow{2}{*}{1,25} & \multirow{2}{*}{0,03} & \multirow{2}{*}{0,04} \\
\hline & & 2012. & 1,25 & & & \\
\hline
\end{tabular}

Izvor: Ikanović i sur. (2013.)

Source: Ikanović et al. (2013)

Rezultati ovih istraživanja pokazali su da postoje značajne razlike $\mathrm{u}$ vrijednostima proučavanih parametara, ali su, u cjelini postignuti 
zadovoljavajući prinosi zrna. U najpovovoljnijim zemljišnim uvjetima prinosi zrna heljde bili su veći oko 30\% nego na lokalitetu Nova Varoš (iznad $1.000 \mathrm{~m}$ nadmorske visine), ali su vremenski uvjeti najviše utjecali na porast biljaka $i$ prinos zrna u ravničarskom području.

Kvinoja se uzgaja i radi mladih listova i zrelog zrna koji se koriste za spremanje ukusnih jela povećane nutritivne vrijednosti. Porijeklom je s visokih planina Južne Amerike i u Srbiji se na oglednim poljima uzgaja oko 10 godina, kako u ravničarskim, tako $\mathrm{i}$ u brdsko-planinakim i visokim planinskim predjelima (Đurić i sur. 2015.). Dobijeni rezultati pokazuju da se može uzgajati u ovim predjelima uz vrlo mala variranja u prinosu zrna. Zrno je visoke hranive i probavljive vrijednosti i vrlo ugodnog ukusa. Prikladno je za spremanje različitih jela, kao i dodatak kruhu (Stikic et al., 2012.). Prema dosadašnjim rezultatima agroekološki uvjeti imaju mali utijecaj na kvalitetu zrna (tablica 4).

Tablica 4. Kemijski sastav zrna dvije sorte kvinoje uzgojene u Staroj Pazovi i Kučajni

Table 4 Chemical grain composition of two quinoa varieties grown in Stara Pazova and Kučajna

\begin{tabular}{|c|c|c|c|c|}
\hline \multirow{2}{*}{$\begin{array}{c}\text { Kemijski } \\
\text { sastav zrna,\% }\end{array}$} & \multicolumn{2}{|c|}{ Lokalitet Stara Pazova } & \multicolumn{2}{|c|}{ Lokalitet Kučajna } \\
\hline & Sorta KVL 52 & Sorta KVL 37 & Sorta KVL 52 & Sorta KVL 37 \\
\hline \multirow{2}{*}{$\begin{array}{c}\text { Chemical } \\
\text { composition of grain, } \%\end{array}$} & \multicolumn{2}{|c|}{ Site Stara Pazova } & \multicolumn{2}{|c|}{ Site Kučajna } \\
\hline & Variety KVL 52 & Variety KVL 37 & Variety KVL 52 & Variety KVL 37 \\
\hline $\begin{array}{l}\text { Vlažnost } \\
\text { Humidity }\end{array}$ & $10,90 \mathrm{NS}$ & $10,87 \mathrm{NS}$ & $12,20 *$ & $11,97 *$ \\
\hline $\begin{array}{l}\text { Proteini } \\
\text { Protein }\end{array}$ & $17,43 * *$ & $15,24 * *$ & $16,23 * *$ & $15,13 * *$ \\
\hline $\begin{array}{l}\text { Skrob } \\
\text { Starch }\end{array}$ & $52,2 * *$ & $56,1 * *$ & $63,8 *$ & $65,1 *$ \\
\hline $\begin{array}{l}\text { Ulja } \\
\text { Oils }\end{array}$ & $4,92 *$ & $4,27 *$ & $4,42 *$ & $4,17 *$ \\
\hline $\begin{array}{l}\text { Celuloza } \\
\text { Cellulose }\end{array}$ & $9,18 \mathrm{NS}$ & $9,20 \mathrm{NS}$ & $9,18 \mathrm{NS}$ & $9,19 \mathrm{NS}$ \\
\hline $\begin{array}{l}\text { Mineral soli } \\
\text { Mineral salts }\end{array}$ & $7,58 *$ & $6,28 *$ & $7,82 *$ & $6,89 *$ \\
\hline $\begin{array}{l}\text { Kalcijum } \\
\text { Calcoim }\end{array}$ & $0,58 *$ & $0,398 *$ & $0,55 *$ & $0,49 *$ \\
\hline $\begin{array}{l}\text { Fosfor } \\
\text { Phosphorus }\end{array}$ & $0,19 \mathrm{NS}$ & $0,22 \mathrm{NS}$ & $0,19 *$ & $0,21 *$ \\
\hline $\begin{array}{l}\mathrm{NaCl} \text { i Na } \\
\mathrm{NaCl} \text { and } \mathrm{Na}\end{array}$ & $\begin{array}{l}0,438 \mathrm{NaCl} \\
0,173 \mathrm{Na}^{*}\end{array}$ & $\begin{array}{l}0,50 \mathrm{NaCl} \\
0,19 \mathrm{Na}^{*}\end{array}$ & $\begin{array}{l}0,44 \mathrm{NaCl} \\
0,18 \mathrm{Na}^{*}\end{array}$ & $\begin{array}{c}0,51 \mathrm{NaCl} ; \\
0,19 \mathrm{Na}^{*}\end{array}$ \\
\hline
\end{tabular}

Izvor: Demin i sur. (2012.)

Source: Demin et al. (2012) 
Krupnik je jedna od najstarijih vrsta pšenice koja u novije vrijeme postaje sve više zastupljena u pripremi visokokvalitetnih krušno-pekarskih proizvoda. Važnost ove vrste ogleda se i u činjenici da se može uzgajati u manje povoljnim agroekološkim uvjetima nego obična pšenica. Prikladan je i za uzgajanje u sistemu ekološke proizvodnje, tako da se zrno koristi za proizvodnju zdravstveno sigurne i funkcionalne hrane. U Srbiji se površine pod krupnikom povećavaju kako raste i potražnja za zrnom ove pšenice. Treba istaći da krupnik dobro uspijeva i na marginalnim zemljištima (Tablica 5).

Tablica 5. Produktivne osobine pšenice krupnik na černozemu i deposolu

Table 5 Production traits of krupnik wheat on chernozem and deposol

\begin{tabular}{|l|c|c|c|c|c|c|}
\hline $\begin{array}{c}\text { Osobine, } \\
\text { lokalitet, } \\
\text { godina }\end{array}$ & $\begin{array}{c}\text { Visina } \\
\text { stabljike, } \\
\mathrm{cm}\end{array}$ & $\begin{array}{c}\text { Dužina } \\
\text { klasa, } \\
\mathrm{cm}\end{array}$ & $\begin{array}{c}\text { Broj klasića } \\
\text { u klasu }\end{array}$ & $\begin{array}{c}\text { Broj zrna } \\
\text { u klasu }\end{array}$ & $\begin{array}{c}\text { Masa zrna u } \\
\text { klasu, g }\end{array}$ & $\begin{array}{c}\text { Prinos } \\
\text { zrna, } \\
\text { kg ha }^{-1}\end{array}$ \\
\hline $\begin{array}{c}\text { Traits, } \\
\text { site, } \\
\text { year }\end{array}$ & $\begin{array}{c}\text { Stalk height, } \\
\text { cm }\end{array}$ & $\begin{array}{c}\text { Spike } \\
\text { length, } \\
\text { cm }\end{array}$ & $\begin{array}{c}\text { No. of } \\
\text { spikelets in } \\
\text { a spike }\end{array}$ & $\begin{array}{c}\text { No. of } \\
\text { grains in } \\
\text { a spike }\end{array}$ & $\begin{array}{c}\text { Grain weight } \\
\text { in a spike, g }\end{array}$ & $\begin{array}{c}\text { Grain } \\
\text { yield, } \\
\text { kg ha }^{-1}\end{array}$ \\
\hline ITP*, 2012. & 107,4 & 12,55 & 19,58 & 29,12 & 1,06 & 2.850 \\
\hline ITP, 2013. & 121,7 & 13,53 & 21,28 & 31,17 & 1,48 & 3.170 \\
\hline $\begin{array}{l}\text { Prosek } \\
\text { Average }\end{array}$ & 114,6 & 13,04 & 20,43 & 30,15 & 1,27 & 3.010 \\
\hline TENT**, 2012. & 77,7 & 8,63 & 18,87 & 24,33 & 1,03 & 2.107 \\
\hline TENT, 2013. & 80,3 & 9,23 & 19,55 & 27,55 & 1,09 & 2.350 \\
\hline $\begin{array}{l}\text { Prosek } \\
\text { Average }\end{array}$ & 79,0 & 8,93 & 19,21 & 25,94 & 1,06 & 2.229 \\
\hline $\begin{array}{l}\text { Ukupni prosek } \\
\text { Overall average }\end{array}$ & 96,8 & 10,99 & 19,82 & 28,05 & 1,17 & 2.620 \\
\hline
\end{tabular}

*Institut Tamiš, Pančevo (černozem), ** Termoelektrana Obrenovac (deposol)

*Institute Tamiš, Pančevo (chernozem), ** Termoelectric plant Obrenovac (deposol)

Izvor: Glamočlija i sur. (2013.)

Source: Glamočlija et al. (2013)

Korasan pšenica je drevna vrsta slična tvrdoj pšenici. Odlikuje se krupnim zrnom s više monosaharida i proteina kvalitetnijeg aminokiselinskog sastava. Veoma je zastupljena u prehrambenim proizvodima povećane nutritivne i energetske vrednosti. U proteklom desetljeću mali poljoprivredni proizvođači pokazuju interes za uzgajanje ove pšenice, uglavnom u sistemu ekološke poljoprivrede. Rezulatati naših istraživanja pokazuju da je korasan pšenica prikladna za uzgajanje u različitim agroekološkim uvjetima $i$ da povoljno reagira na pojačanu dopunsku ishranu biljaka (Tablica 6). 
N. Đurić i sur.: Alternativne žitarice u Srbiji

u sistemu održive poljoprivredne proizvodnje

Tablica 6. Pokazatelji morfoloških i produktivnih osobina korasan pšenice

Tablea 6 Indicators of morphological and production traits of korasan wheat

\begin{tabular}{|c|c|c|c|c|c|c|c|}
\hline \multirow{2}{*}{$\begin{array}{c}\text { Morfološke i } \\
\text { produktivne osobine }\end{array}$} & \multicolumn{4}{|c|}{ Dopunska ishrana biljaka } & \multicolumn{3}{|c|}{ Agroekološki uvjeti } \\
\hline & Kontrola & $\begin{array}{c}\text { NPK - } \\
70: 45: 45\end{array}$ & \begin{tabular}{|c|} 
NPK - \\
$99: 45: 45$
\end{tabular} & Prosjek & Srijem & Šumadija & Prosjek \\
\hline \multirow[b]{2}{*}{$\begin{array}{l}\text { Morphological and } \\
\text { production traits }\end{array}$} & \multicolumn{4}{|c|}{ Supplementary plant nutrition } & \multicolumn{3}{|c|}{ Agroecological conditions } \\
\hline & Control & $\begin{array}{l}\text { NPK - } \\
70: 45: 45\end{array}$ & \begin{tabular}{|c|} 
NPK - \\
$99: 45: 45$
\end{tabular} & Average & Srijem & Šumadija & Average \\
\hline $\begin{array}{l}\text { Broj klasova na } \\
1 \text { dužni metar } \\
\text { No. of spikes per } \\
1 \text { m length }\end{array}$ & 32,7 & 41,9 & 50,7 & 45,1 & 50,3 & 40,9 & 45,1 \\
\hline $\begin{array}{l}\text { Visina stabljike, cm } \\
\text { Stalk height, cm }\end{array}$ & 83,2 & 113,6 & 118,5 & 106,7 & 114,3 & 99,2 & 106,7 \\
\hline $\begin{array}{l}\text { Broj listova na stabljici } \\
\text { No of leaves } \\
\text { on the stalk }\end{array}$ & 4,3 & 4,6 & 4,6 & 4,5 & 4,6 & 4,4 & 4,5 \\
\hline $\begin{array}{l}\text { Dužina lista } \\
\text { zastavičara, cm } \\
\text { Lenth of flag leaf, cm }\end{array}$ & 23,66 & 24,82 & 27,48 & 26,15 & 27,84 & 24,46 & 26,15 \\
\hline $\begin{array}{l}\text { Dužina klasa, } \mathrm{cm} \\
\text { Spike length, } \mathrm{cm}\end{array}$ & 8,6 & 10,4 & 11,2 & 10,02 & 9,5 & 10,53 & 10,02 \\
\hline $\begin{array}{l}\text { Masa klasa, g } \\
\text { Spike weight, g }\end{array}$ & 1,33 & 1,45 & 1,50 & 1,430 & 1,555 & 1,290 & 1,430 \\
\hline $\begin{array}{l}\text { Masa stabllijike, } g \\
\text { Stalk weight, g }\end{array}$ & 1,28 & 1,57 & 1,70 & 1,52 & 1,69 & 1,24 & 1,52 \\
\hline $\begin{array}{l}\text { Masa biljke, } g \\
\text { Plant weight, } g\end{array}$ & 2,60 & 3,01 & 3,21 & 2,94 & 3,25 & 2,63 & 2,94 \\
\hline $\begin{array}{l}\text { Broj zrna u klasu } \\
\text { No. of grains per spike }\end{array}$ & 16,7 & 20,9 & 21,9 & 19,7 & 20,88 & 18,55 & 19,71 \\
\hline $\begin{array}{l}\text { Masa zrna u klasu, } \mathrm{g} \\
\text { Spike grain weight, } \mathrm{g}\end{array}$ & 0,90 & 1,26 & 1,33 & 1,16 & 1,32 & 1,00 & 1,16 \\
\hline $\begin{array}{l}\text { Masa } 1.000 \text { semena, } \mathrm{g} \\
1,000 \text { grain weight, } \mathrm{g}\end{array}$ & 57,3 & 65,8 & 64,9 & 62,6 & 63,6 & 61,7 & 62,1 \\
\hline $\begin{array}{l}\text { Žetveni indeks, \% } \\
\text { Harvest Index,\% }\end{array}$ & 39,74 & 41,67 & 41,13 & 39,83 & 40,44 & 39,22 & 39,83 \\
\hline
\end{tabular}

Izvor:Glamočlija i sur. (2017.)

Source: Glamočlija et al. (2017)

Kanarska trava, se uzgaja radi zrna koje je nezamjenljiva komponenta hrane za kavezne ptice, ali se, oljušteno, koristi i kao vrlo hraniv dodatak brojnim jelima. U Srbiji se uzgaja na malim površinama tako da se naše ukupne potrebe podmiruju uvozom. Mi imamo dvije domaće sorte prilagođene našim 
agroekološkim uvjetima. Mali broj farmera koji uzgajaju ovu biljku postižu prinose na nivou svjetskog prosjeka. Rezultati istraživanja proizvedenih na području sjeverne Šumadije tijekom 2003. i 2004. godine, pokazali su genetičku uniformnost domaćih sorti, kao i da su prikladne za uzgajanje na siromašnijim zemljištima. Međutim, izražena sukcesivnost u sazrijevanju nije dala odgovor kada početi žetvu i kako je obaviti. U jednofaznoj žetvi bilo je i do $22 \%$ nedozrelih cvasti što je značajno umanjilo prinos zrelog zrna (Kajgana i sur., 2004).

Proso (čumiza), zahvaljujući velikoj hranivoj vrijednosti zrna, postaje sve interesantnije za spremanje lako probavljive hrane za djecu i sportaše. $\mathrm{S}$ agronomske točke gledišta ovo su biljke koje uspijevaju u raznovrsnim agroekološkim uvjetima, a kratak vegetacijski period pruža farmerima mogućnost da ih siju u različitim rokovima, od proljetnog, do postrnog (Đurić i sur., 2018., Tablica 7). Ubuduće bi trebale zauzeti značajnije površine na imanjima malih farmera, i to kao naknadni i postrni usjevi. Prema rezultatima naših istraživanja daju dobre prinose koristeći biljne asimilative od predusjeva, ali pozitivno reagiraju i na pojačanu ishranu azotom (Tablica 8).

Tablica 7. Utjecaj vremena sjetve na prinos zrna prosa

Table 7 Effect of seeding time on grain yield of millet

\begin{tabular}{|c|c|}
\hline $\begin{array}{l}\text { Vrijeme sjetve } \\
\text { Seeding time }\end{array}$ & $\begin{array}{l}\text { Prinos zrna, } \mathrm{kg} \mathrm{ha}^{-1} \\
\text { Grain yield, } \mathrm{kg} \mathrm{ha}^{-1}\end{array}$ \\
\hline $\begin{array}{l}\text { 24. svibnja } \\
24 \text { May }\end{array}$ & 6.185 \\
\hline $\begin{array}{l}\text { 6. lipnja } \\
\text { 6 June }\end{array}$ & 5.795 \\
\hline $\begin{array}{l}\text { 22. lipnja } \\
\text { 22 June }\end{array}$ & 3.175 \\
\hline $\begin{array}{l}\text { 8. srpnja } \\
8 \text { July }\end{array}$ & 2.099 \\
\hline $\begin{array}{l}\text { Prosjek za rokove } \\
\text { Term average }\end{array}$ & 4.314 \\
\hline
\end{tabular}

Izvor: Đurić i sur. (2018.)

Source: Đurić et al. (2018)

Na ukupan prinos prosa vremenski uvjeti nisu imali veći ujecaj, tako da je u prvoj godini ova vrijednost bila $4.314 \mathrm{~kg} \mathrm{ha}^{-1}$, a u drugoj, s više padalina, oko $15 \%$ manja. 
N. Đurić i sur.: Alternativne žitarice u Srbiji

u sistemu održive poljoprivredne proizvodnje

Tablica 8. Utjecaj povećanih količina azota na prinos zrna prosa, čumize i kanarske trave, $\mathrm{kg} \mathrm{ha}^{1}$

Table 8 Effect of increased nitrogen content on grain yield of millet, italian millet and canary grass, $\mathrm{kg} \mathrm{ha}^{1}$

\begin{tabular}{|l|c|c|c|}
\hline \multicolumn{1}{|c|}{$\begin{array}{c}\text { Varijanta ishrane } \\
\text { Fertilization variant }\end{array}$} & $\begin{array}{c}\text { Proso } \\
\text { Millet }\end{array}$ & $\begin{array}{c}\text { Čumiza } \\
\text { Italian millet }\end{array}$ & $\begin{array}{c}\text { Kanarska trava } \\
\text { Canary grass }\end{array}$ \\
\hline $\begin{array}{l}\text { Kontrola } \\
\text { Control }\end{array}$ & 825 & 802 & 797 \\
\hline $\begin{array}{l}\text { Varijanta sa } 50 \mathrm{~kg} \mathrm{ha}^{-1} \text { azota } \\
\text { Variant with } 50 \mathrm{~kg}^{-1} \text { nitrogen }\end{array}$ & 1.198 & 976 & 912 \\
\hline $\begin{array}{l}\text { Varijanta sa } 100 \mathrm{~kg} \mathrm{ha}^{-1} \text { azota } \\
\text { Variant with } 100 \mathrm{~kg} \mathrm{ha}^{-1} \text { nitrogen }\end{array}$ & 1.272 & 1.066 & 935 \\
\hline $\begin{array}{l}\text { Prosječan prinos } \\
\text { Average yield }\end{array}$ & 1.098 & 948 & 881 \\
\hline
\end{tabular}

Izvor:Crnogorac i sur. (2005.)

Source:Crnogorac et al. (2005)

Kukuruz šećerac je u proteklim desetljećim postao značajna ratarska biljka koju sve više uzgajaju, kako mali farmeri, tako i veliki poljoprivredni proizvođači sijući ga u različitim rokovima uz obavezno navodnjavanje usjeva. Kao i ostale forme, šećerac je biljka visoke agrotehnike tako da se primjenom suvremenih vodotopivih biljnih hraniva postižu značajno veći prinosi i bolja kvaliteta zrna (Glamočlija i sur., 2003., Tablica 9).

Tablica 9. Prosječna masa klipa kukuruza šećerca u uvjetima dopunske ishrane biljaka, g

Table 9 The average mass of corn pumice in the conditions of supplemental feeding of plants, $g$

\begin{tabular}{|l|c|c|c|c|c|}
\hline \multicolumn{1}{|c|}{$\begin{array}{c}\text { Varijanta godina } \\
\text { Variant year }\end{array}$} & $\begin{array}{c}\text { Kontrola } \\
\text { Control }\end{array}$ & NPK & Cropcare 1 & Cropcare 3 & $\begin{array}{c}\text { Prosjek } \\
\text { Average }\end{array}$ \\
\hline $\begin{array}{l}\text { Prva } \\
1^{\text {st }}\end{array}$ & 130 & 136 & 152 & 136 & 139 \\
\hline $\begin{array}{l}\text { Druga } \\
2^{\text {nd }}\end{array}$ & 128 & 156 & 177 & 166 & 157 \\
\hline $\begin{array}{l}\text { Prosjek } \\
\text { Average }\end{array}$ & 129 & 146 & 165 & 151 & 148 \\
\hline
\end{tabular}

$\mathrm{LSD}_{\text {ishrana }} 1 \%=19,2 ; 5 \%=13,4 \quad \mathrm{LSD}_{\text {godina }} 1 \%=20,6 ; 5 \%=14,3 \quad \mathrm{LSD}_{\mathrm{Ab}} 1 \%=21,9 ; 5 \%=15,2$

Miskantus je po botaničkim osobinama, svrstan u alternativna žita, ali se uzgaja radi nadzemne biomase koja se svježa koristi kao stočna hrana, a suha (ili sveža) za proizvodnju čvrstih i plinskih biogoriva. Postaje sve interesantniji za ovaj način korištenja otkako se većina zemalja u svijetu uključila u program 
osiguranja goriva iz obnovljivih izvora i da bi se smanjilo ispuštanje plinova u atmosferu koji povećavaju efekt staklenika (Djuric and Glamoclija 2018.). Miskantus se može uzgajati na različitim zemljištima, od deposola, do najplodnijih, ali najbolje rezultate daje primjenom intenzivne agrotehnike (Ikanović i sur., 2015.; Glamočlija et al., 2018.), Tablica 10.

Tablica 10. Utjecaj azota i gustoće sadnje na morfološke osobine miskantusa (prosjek 2009/10.)

Table 10 Effect of nitrogen and planting density on morphological traits of miscanthus (2009/10 average)

\begin{tabular}{|l|c|c|c|c|c|c|c|}
\hline \multicolumn{1}{|c|}{$\begin{array}{c}\text { Tretman } \\
\text { Treatment }\end{array}$} & $\begin{array}{c}\text { Kontrola } \\
\text { Control }\end{array}$ & N 60 & N100 & $\begin{array}{c}\text { Prosjek } \\
\text { Average }\end{array}$ & $\begin{array}{c}\text { 2 rizoma, } \mathrm{m}^{2} \\
\text { 2 rhizomes, } \mathrm{m}^{2}\end{array}$ & $\begin{array}{c}3 \text { rizoma, } \mathrm{m}^{2} \\
\text { 3 rhizomes, } \mathrm{m}^{2}\end{array}$ & $\begin{array}{c}\text { Prosjek } \\
\text { Average }\end{array}$ \\
\hline $\begin{array}{l}\text { Visina biljke, cm } \\
\text { Plant height, cm }\end{array}$ & 109 & 146 & 344 & 199,7 & 147 & 138 & 142,5 \\
\hline $\begin{array}{l}\text { Broj stabljke } \\
\text { No. of stalks }\end{array}$ & 8,9 & 9,4 & 9,8 & 9,37 & 6,9 & 23,6 & 15,25 \\
\hline $\begin{array}{l}\text { Broj listova } \\
\text { No. of leaves }\end{array}$ & 5,5 & 6,0 & 6,8 & 5,77 & 6,9 & 5,2 & 6,05 \\
\hline
\end{tabular}

Izvor: Dželetović i Glamočlija (2015.)

Source: Dželetović and Glamočlija (2015)

\section{ZAKLJUČAK}

$\mathrm{Na}$ osnovi rezultata dosadašnjih istraživanja može se zaključiti da $u$ poljoprivrednim predjelima Srbije postoje vrlo povoljni agroekološki uvjeti za uzgajanje alternativnih žita na malim površinama u sistemu održive i ekološke (organske) proizvodnje. Većinu navedenih vrsta naši farmeri uzgajaju i postižu bolje financijske efekte nego $\mathrm{u}$ proizvodnji standardnih ratarskih usjeva. Za određeni broj alternativnih žita postoji interesovanje, ali se teško dolazi do kvalitetnog sjemena, drugi problem je dalja prerada zrna, jer su ona većinom obrasla čvrstim omotačima koji se ljušte specijalnim mašinama. Jedno od rješenja za ova dva osnovna problema bilo bi u udruživanju malih farmera i nabavi uvoznog kvalitetnog, konvencionalnog i organskog sjemena, kao i ljuštilica, kako bi tržištu ponudili proizvode s visokim stupnjom dorade. Drugo rješenje bilo bi u državnim poticajima, kojima bi se olakšala i unaprijedila ova specifična proizvodnja. Time bi se mali farmeri u većem broju odlučivali za uzgajanje alternativnih žita. 
N. Đurić i sur.: Alternativne žitarice u Srbiji

u sistemu održive poljoprivredne proizvodnje

\section{LITERATURA}

1. Crnogorac, M., Đ. Glamočlija, V. Milić, G. Kulić (2005.): Uticaj mineralne ishrane na gajenje sitnozrnih prosolikuh žita u Sarajevskom polju. X Naučno stručno savjetovanje agronoma Republike Srpske sa međunarodnim učešćem "Naučna podrška razvojnoj strategiji poljoprivrede Republike Srpske", Teslić, Republika Srpska, Zbornik radova.

2. Demin, M., M. Milovanović, Dj. Glamočlija and B. Vucelić-Radović (2012.): Quinoa - a new high quality crop in Serbia. Zemljište i biljka, Vol. 61, No. 2, str. 107-118.

3. Đurić, N., B. Kresović, Glamočlija, Đ. (2015.): Sistemi konvencionalne i organske proizvodnje ratarskih useva. Monografija, Izdavač: Institut PKB Agroekonomik, Beograd. ISBN 978-86-89859-01-0, COBISS.SR-ID 218749452, CIP 633.1/.7,631.147

4. Djuric, N., Glamoclija, Dj. (2018.): Introduction of mischantus in agricultural production in Serbia and the potential for using biomass for obtaining alternative fuels. Suistainable agriculture and rural development in terms of the Republic of Serbia strategic goals realization within the Danube region support programs for the improvement of agricultural and rural development. Thematic Proceedings, 453-470. Publisher: Institute of Agricultural Economics, Belgrade, Serbia. ISBN 978-86-6269-061-6. COBISS.SR-ID 257428748

5. Đurić, N., Ž. Horvat, G. Cvijanović, Đ. Glamočlija, G. Dozet, V. Cvijanović (2018.): Efekat roka setve na prinos i neke osobine običnog prosa (Panicum miliaceum L). XXXII Savetovanje agronoma, veterinara, tehnologa i agroekonomista Instituta PKB Agroekonomik, Padinska Skela, Beograd. Zbornik radova,vol. 24, br. 1-2, str.87-93.

6. Dželetović, $Z \check{~ a n d ~} Đ$. Glamočlija (2015.): Effect of nitrogen on the distribution of biomass and element composition of the root system of miscanthus $\times$ giganteus. Archives of Biological Sciences, 2015 On Line-First (00), pp.547560.

7. Glamočlija, Đ., J. Ikanović, M. Spasić (2003.): Uticaj dopunske ishrane kukuruza šećerca ekološkim minerlnim hranivima na prinos i kvalitet zrna i nadzemne biomase. Agroinovacije, Zbornik rezimea, str.13-15, Niška Banja.

8. Glamočlija, Đ., M. Staletić, J. Ikanović, M. Spasić, V. Đekić and M. Davidović (2010): Possibilities alternative grain production in the highlands area of central Serbia. International Scientific Meeting: Multifunctional Agriculture and Rural Development (V) II Book, pp. 71-77. 
N. Đurić i sur.: Alternativne žitarice u Srbiji

u sistemu održive poljoprivredne proizvodnje

9. Glamočlija, Đ., S. Janković i R. Pivić (2012.): Alternativna žita, Monografija. Institut za zemljište, Beograd.

10. Glamočlija, Đ.(2012.): Sve traženija alternativna, nova - stara žita. U: Žebeljan D. (urednik), Knjiga Poljoprivrednikov Poljoprivredni kalendar: nova saznanja, dostignuća, iskustva, AD Dnevnik Poljoprivrednik, Novi Sad, str. 298-301.

11. Glamočlija, Đ., S. Janković, V. Popović, V. Ugrenović, N. Zekić and J. Ikanović (2013.): Morphological and productivitycharacteristics of spelt wheat on the chernozem and degraded soil.Proceedings, 4th International Agronomic Symposium “Agrosym 2013”, Jahorina, pp. 364-369.

12. Glamočlija, Đ., S. Janković, V. Popović, V. Filipović, V. Ugrenović, J. Kuzevski (2015.): Alternativne ratarske biljke u konvencionalnom i organskom sistemu gajenja. Monografija, Izdavač, IPN, Beograd, ISBN 978-86-81689-325; str. 1-355.

13. Glamočlija, Đ., S. Janković, J. Kuzevski, N. Đurić, A. Omar Alkhammas, N. Glamočlija, J. Maksimović (2017.): Uticaj povećanih količina azota i tipa zemljišta na morfološke i proizvodne osobine korasan pšenice. XXXI Savetovanje agronoma, veterinara, tehnologa i agroekonomista, Instituta PKB Agroekonomik, Padinska Skela. Zbornik radova, vol. 23, br. 1-2, str.61-70.

14. Glamočlija, Đ., N. Đurić, M. Spasić (2018.): The influence of agro-ecological conditions on the production properties of miscanthus. Proceedings 8th International Symposium On Natural Resources Managment, 19. May, Megatrend University, Faculty of Managment, Zaječar, Serbia, 173-178. ISBN 978-867747-590-1

15. Ikanović, J., S. Rakić, V. Popović, S. Janković, Đ. Glamočlija and J. Kuzevski (2013.): Agro-ecological conditions and morphoproductive properties of buckwheat. Biotechnology in Animal Husbandry, 29 (3), pp. 555-562.

16. Ikanović, J., V. Popović, S. Janković, Lj. Živanović, S. Rakić, D. Dončić (2014.): Khorasan wheat population researching (Triticum turgidum, sp. Turanicum McKEY) in the minimum tillage conditions. Genetika, Belgrade, 46 (1), pp. 105-115.

17. Ikanović, J., V. Popović, S. Janković, S. Rakić, G. Dražić, LJ. Živanović, LJ. Kolarić, Ž. Lakić (2015.): Produkcija biomase miskantusa gajenog na degradiranom zemljištu. XXIX Savetovanje agronoma, veterinara, tehnologa i agroekonomista, Instituta PKB Agroekonomik, Padinska Skela. Zbornik radova, vol. 21. br. 1-2, 115-124.

18. Jankovic, S., Dj. Glamoclija, R. Maletic, S. Rakić, N. Hristov, J. Ikanovic (2011.): Effects of nitrogen fertilization on yield and grain quality in malting barley. African Journal of Biotechnology, Vol. 10 (84), pp. 19534-19541. 
N. Đurić i sur.: Alternativne žitarice u Srbiji

19. Jevđović, R., G.Todorović, M. Kostić (2015.): Proizvodnja manje zastupljenog lekovitog bilja. izdavač "Akademska izdanja" d.o.o.. Zemun. ISBN: 978-8689279-06-1.

20. Kajgana, M., Đ. Glamočlija, G. Vanka (2004.): Rezultati introdukcije kanarske trave (Phalaris canariensis L.) u ratarsku proizvodnju centralen Srbije. Acta Agriculturae Serbica, vol. IX, 17, str. 553-558.

21. Maksimović, J., R. Pivić, A. Stanojković-Sebić, M. Vučić-Kišgeci, B. Kresović, Z. Dinić and Đ. Glamočlija (2016.): Planting density impact on weed infestation and the yield of Miscanthus grown on two soil types. Plant, Soil and Environment, 62, Issue No. 10 (8), pp. 384-388.

22. Popović, V., V. Sikora, Đ. Glamočlija, J. Ikanović, V.Filipović, M. Tabaković and D. Simić (2013.): Influence of agro-ecological conditions and foliar fertilization on yield and yield components of buckwheat in conventional and organic cropping system. Biotechnology in Animal Husbandry, 29 (3), pp. 537-546.

23. Sikora, V., V. Filipović, J. Berenji and V. Popović (2013.): Agro-biological traits of genotypes of common millet (Panicum miliaceum L.) in regular and stubble crop. Field and Vegetable, Novi Sad, 50 (1), rr. 16-23.

24. Stallknecht, G., K. Gilbertson, and J. Ranney (1996.): Alternative wheat cereals as food grains: Einkorn, emmer, spelt, kamut, and triticale. Progress in new crops. ASHS Press, Alexandria, VA. p. 156-170. In: J. Janick (ed.).

25. Stikic, R., Dj. Glamoclija, M. Demin, B. Vucelic-Radovic, Z. Jovanovic, D. Milojkovic-Opsenica, S. E. Jacobsenand M. Milovanovic (2012.): Agronomical and nutritional evaluation of quinoa seeds (Chenopodium quinoa Willd.) as an ingredient in bread formulations. Journal of Cereal Science, XXX, 1-7 Ms. No. JCS11-221R1.

26. Žeželj, M., M. Demin, S. Rakić (1995.): Izučavanje nekih osobina žita značajnih za unapređenje postojećih i razvoj novih tehnologija: mlinski aspekti proivodnje intnjgralnog brašna od pšenice i raži, U: Osnovna istraživanja u prehrambenoj tehnologiji. Monografija, beograd, poljoprivreni fakultet, Institut za prehrambenu tehnologiju i biohemiju, str. 102-112. 
Adrese autora - Author addresses:

Dr. Nenad Đurić, docent e-mail: nenad.djuric@outlook.com

tel: +38124712209

Dr. Gordana Dozet, vanredni profesor e-mail: gdozet@biofarming.edu.rs tel: +38124712209

Univerzitet „Megatrend“, Beograd

Fakultet za biofarming, Bačka Topola

Maršala Tita, broj 39, Bačka Topola, Srbija

Dr Đorđe Glamočlija, redovni profesor

e-mail: lami.agrif@gmail.com

tel: +381641711323

Društvo selekcionera i semenara Srbije,

Slobodana Bajića 1, Beograd, Srbija

Dr Snežana Janković, redovni profesor

e-mail: sjankovic@ipn.bg.ac.rs

tel: +3811112751622

Milena Glamočlija, master student

tel: +3811112751622

e-mail: lami.agrif@gmail.com

Institut za primenu nauke u poljoprivredi,

Bulevar Despota Stefana 68 b, Beograd, Srbija

Dr Vera Popović, viši naučni saradnik

e-mail: bravera@eunet.rs

Institut za ratarstvo i povrtarstvo,

Maksima Gorkog 30, Novi Sad, Srbija

Vojin Cvijanović, doktorant

e-mail: cvija91@yahoo.com

tel: +381114413239

Univerzitet u Beogradu, Beograd

Poljoprivredni fakultet, Beograd

Nemanjina, broj 6, Beograd-Zemun, Srbija
Primljeno- Received

15.10.2018. 